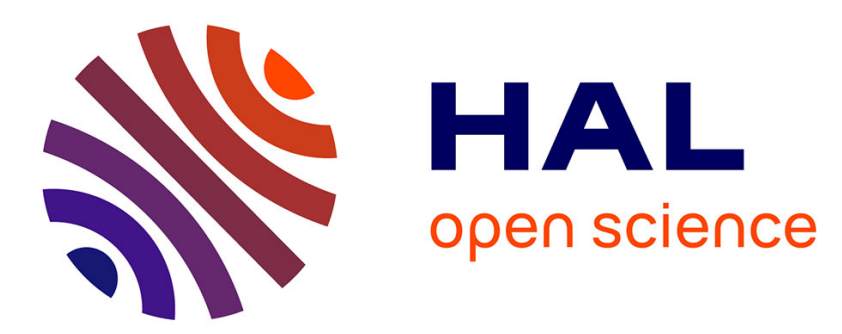

\title{
Trade Integration and Business Cycle Synchronization in the EMU: the Negative Effect of New Trade Flows
}

Jean-Sébastien Pentecôte, Jean-Christophe Poutineau, Fabien Rondeau

\section{To cite this version:}

Jean-Sébastien Pentecôte, Jean-Christophe Poutineau, Fabien Rondeau. Trade Integration and Business Cycle Synchronization in the EMU: the Negative Effect of New Trade Flows. Open Economies Review, 2015, 26 (1), pp.61-79. 10.1007/s11079-014-9318-8 . hal-02440559

\section{HAL Id: hal-02440559 \\ https://hal.science/hal-02440559}

Submitted on 15 Jan 2020

HAL is a multi-disciplinary open access archive for the deposit and dissemination of scientific research documents, whether they are published or not. The documents may come from teaching and research institutions in France or abroad, or from public or private research centers.
L'archive ouverte pluridisciplinaire $\mathbf{H A L}$, est destinée au dépôt et à la diffusion de documents scientifiques de niveau recherche, publiés ou non, émanant des établissements d'enseignement et de recherche français ou étrangers, des laboratoires publics ou privés. 


\title{
Trade Integration and Business Cycle Synchronization in the EMU: the Negative Effect of New Trade Flows
}

\author{
J.-S. PENTECOTE ${ }^{a}$ • J.-C. POUTINEAU ${ }^{a}$. $^{-}$ \\ F. RONDEAU ${ }^{a \star}$
}

Received: date / Accepted: date

\begin{abstract}
This paper questions the impact of trade integration on business cycle sychronization in the EMU by distinguishing increase of existing trade flows (the intensive margin) and creation of new trade flows (the extensive margin). Using a DSGE model, we find that synchronization is weakened when new firms are allowed to export as a response to productivity gains. Consistenly with our model and using disaggregated data over 1995-2007 for the 11 founding members of the EMU, we find that trade intensity has a positive direct effect while new trade flows have a negative effect on business cycle synchronization. Furthermore, new flows play essentially an indirect role by intensifying specialization and explain $60 \%$ of the overall effect of trade intensity and specialization on synchronization.
\end{abstract}

Keywords Trade integration · Business cycles · European Monetary Union JEL codes: F41 $\cdot$ F44 $\cdot$ F15

\section{Introduction}

The effect of trade integration on business cycle synchronization remains a key issue for the member countries of the European Monetary Union (EMU). Indeed, having adopted a single currency these countries can no longer use nominal exchange rate to adjust to asymmetric shocks. On the macroeconomic side, the deepening of goods market integration coming from the trade increase should promote closer synchronization of national business cycles in the EMU and give a rise to a European business cycle.

Although the trade effect of the euro has been widely empirically documented in the literature, it is still uncertain. Summarizing the evidence since the influential study of Frankel and Rose (1998), Rose and Stanley (2005) conclude to a positive effect of the European single currency on trade accross the Member States so that their business cycles have become

* The authors are grateful for useful suggestions from two anonymous referees and the editor.

${ }^{a}$ CREM CNRS 6211 - University of Rennes 1

7 place Hoche 35000 Rennes, France

Tel.: +33-2-23233366

Fax: ++33-2-23233599

E-mail: fabien.rondeau@univ-rennes1.fr 
synchronized. This latter finding seems rather optimistic with regard to the more skeptical evidence provided by Berger and Nitch (2008) and by Havránek (2010).

These contrasting findings illustrate the debate regarding the interplay between trade integration and business cycle. Authors such as Baxter and Kouparitsas (2003, 2005), Fonseca et al. (2010) and Dées and Zorell (2012) provide empirical evidence on the strong and positive effect of trade intensity on business cycle synchronization. This effect may interact with other factors such as product diversification, financial factors (Lee and Rhee, 2013) or the convergence in macroeconomic policies according to Inklaar et al. (2008). In contrast, Abbott et al. (2008) find that the dependence of business cycle on trade intensity is both timely and geographically dependent, being negative in some cases.

Our paper questions the impact of trade integration on business cycle synchronization in the EMU, by distinguishing the trade increase that comes from existing trade flows (namely the intensive margin of trade) and the creation of new trade flows (the extensive margin of trade). This latter dimension is important for issues related to the member countries of the EMU. As already noticed by Flam and Nordström (2006), the switch to the single currency has increased the number of traded goods in the euro area. This result is in line with Harris et al. (2012) who underline the reciprocal and the mixed transitory/permanent nature of trade flows around the world. On the theoretical front, as discussed by Bergin and Lin (2009, 2012), currency unions may well boost the extensive margin of bilateral trade flows, both in absolute and relative terms. Currency unification induces a reduction in transaction costs - and thereby in trade barriers - between its members. In addition, there is an incentive for firms to invest so as to enter a new export market because monetary unions historically last longer than currency pegs. Improved risk sharing from a deeper financial integration may also lead firms to concentrate on specific production activities, thus inducing foreign trade between countries as they become more specialized (Kalemli-Ozcan et al., 2003, 2005).

To account for the effect of the nature of trade increase on business cycle synchronization, our paper adopts a disaggregated view on bilateral trade flows. Drawing on the CEPIIBACI database, we consider 5,000 bilateral trade flows between the 11 founding countries of the EMU ${ }^{1}$ over the 1995-2007 period. We thus document around 4.7 millions potential trade relationships. Table 1Bilateral Trade Flows among the 11-founders of EMU between 1995 and 2007table.1 reveals that only half of all the recorded bilateral trade flows within the euro area falls into the traded / non traded goods dichotomy (respectively 18\% and 32\%). Transitory trade flows ${ }^{2}$ thus represent $50 \%$ of bilateral trade relations during this 13 -year period, averaging 24,000 new transactions each year.

The bilateral nature of trade flows is important to account for. Indeed, as noticed in figure 1New Trade Flows over time (left) and against country GDP (right)figure.1, the share of new trade flows is variable over time and across countries. This finding is in line with the recent evidence provided by Harris et al. (2012) and Abbott et al. (2008) at the world and at the European levels respectively. New flows seem to follow a decreasing trend from 1995 to 2007 (left). Furthermore, smaller countries are characterized by a higher increase of trade flows (Portugal 12.43\%, Austria 12.37\% and Ireland 12.12\%) while, it represents much less for larger countries such as Germany (5.04\%) or France (7.28\%).

To our knowledge the effect of the transitory nature of bilateral trade flows on bilateral business cycle correlation has not yet been studied in the literature although it should pro-

\footnotetext{
1 Austria, Belgium, Finland, France, Germany, Ireland, Italy, Luxemburg, Netherlands, Portugal, Spain. We aggregate data for Belgium and Luxemburg.

2 New trade flows refer to the number of new trade relationships between two trading partners. In contrast permanent trade refers to situations with positive values for bilateral exchanges during each of the 13 years of the analysis.
} 
Table 1 Bilateral Trade Flows among the 11-founders of EMU between 1995 and 2007.

\begin{tabular}{lcc}
$\begin{array}{l}\text { Occurences } \\
\text { (years) }\end{array}$ & $\begin{array}{c}\text { Number } \\
\text { of flows }\end{array}$ & $\begin{array}{c}\text { Frequency } \\
(\%)\end{array}$ \\
\hline 0 - No Trade & 857,649 & 18 \\
1 -12 - New Trade & $2,354,170$ & 50 \\
13 - Permanent Trade & $1,501,409$ & 32 \\
\hline Total & $4,713,228$ & 100.00
\end{tabular}

Fig. 1 New Trade Flows over time (left) and against country GDP (right)
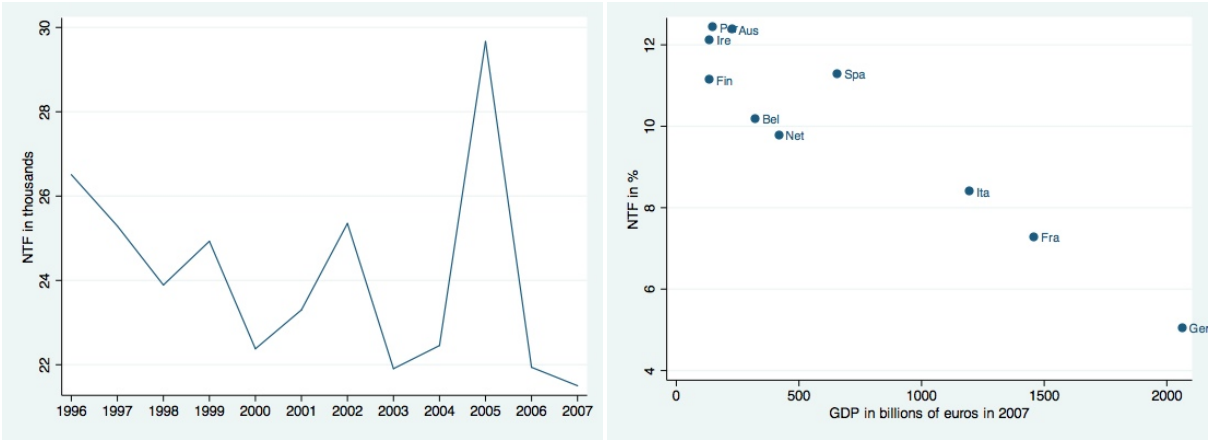

Notes: Bel for Belgium-Luxemburg, Fra for France, Ger for Germany, Ire for Ireland, Ita for Italy, Por for Portugal, Spa for Spain, Net for The Netherlands, Fin for Finland and Aus for Austria.

vide some interesting elements to the debate on the interplay between trade and business cycle synchronization, as coherences reported in table 2Average Coherences between New Trade Flows and Business Cycles Correlations for country $i$ (in column) against the rest of EMUtable. 2 reveal the close association between bilateral trade and the coupling of business cycles.

Table 2 Average Coherences between New Trade Flows and Business Cycles Correlations for country $i$ (in column) against the rest of EMU

\begin{tabular}{c|cccccccccccc}
\hline Country & Bel. & Fra & Ger & Ire & Ita & Por & Spa & Net & Fin & Aus & Average \\
\hline Coherences & 0.67 & 0.66 & 0.72 & 0.72 & 0.57 & 0.67 & 0.72 & 0.66 & 0.78 & 0.71 & 0.69 \\
\hline
\end{tabular}

Notes: Coherences go from 0 (no correlations) to 1 (perfect correlations). The $5 \%$ critical level is 0.51 .

The aim of this paper is to understand how the distinction between the extensive and intensive margins of trade may account for the heterogenous evidence of the link between trade integration and business cycle synchronization.

First, we introduce an illustrative dynamic stochastic general equilibrium model following the recent literature on the extensive margin of international trade (Bilbiie et al., 2012; Corsetti et al., 2013). We find that the response of the cyclical component of output to a 
positive specific productivity shock depends on the variation in the terms of trade. Domestic and foreign outputs tend to move together when trade develops only at the intensive margins. By contrast, the ability of firms to react to shocks by producing and exporting new goods dampens the fluctuations in the terms of trade. The business cycle component in the domestic country becomes less synchronized with regard to its foreign counterpart.

Second, we assess the empirical relevance of the negative contribution of the extensive margin of trade on business cycle synchronization on the 10 founding countries of the EMU over the 1995-2007 period. We adapt the simultaneous equation framework initially developed by Imbs $(2004,2010)$ and extended by Abbott et al. (2008) to a panel data model. In contrast with the existing literature, we consider new trade flows as a separate driver of business cycle synchronization in association with trade intensity and trade structure. Specialization and new trade flows affect negatively business cycle synchronization whereas trade has a positive influence. Two-thirds of the contribution of new trade flows is channeled through specialization. More importantly, our empirical findings show that new trade flows act mainly as a propagation mechanism: more than $60 \%$ of the overall effect of trade intensity and specialization on synchronization is transmitted by new trade flows.

The paper is organized as follows. Section 2 presents the theoretical analysis. Section 3 presents the empirical results. Section 4 concludes.

\section{A model of international trade and business cycle fluctuations with heterogeneous}

\section{firms}

The model describes a two country world with flexible prices. Each country is populated by homogeneous households and heterogeneous firms. Each individual firm is specialized in the production of a given variety of goods that is imperfectly substitutable in the consumers' bundle. Firms belong to the traded or the non traded sector depending on their productivity level. To simplify matters, the capital stock of domestic firms is entirely owned by the residents and the current account is always in equilibrium. Assuming that the structure of countries is symmetric, we present in details the domestic country. Foreign variables are indicated by an asterisk as exponent.

\subsection{Households}

The number of households is normalized to 1 . The consumer $i$ in the domestic country maximizes,

$$
\underset{c_{t}(i), l_{t}(i), b_{t+1}(i)}{\operatorname{Max}} E_{t} \sum_{j=0}^{\infty} \beta^{j}\left[\ln c_{t+j}(i)-\Xi \frac{l_{t+j}(i)^{1+\kappa}}{1+\kappa}\right],
$$

by choosing $c_{t}(i)$ (consumption), $l_{t}(i)$ (labour supply) and $b_{t+1+j}(i)$ (the real amount of private bonds held at the end of period $t$ ), subject to the budget constraint,

$$
E_{t} \beta^{j}\left[w_{t+j} l_{t+j}(i)+b_{t+j}(i)-c_{t+j}(i)-\left(1+r_{t+j}\right)^{-1} b_{t+1+j}(i)\right]=0,
$$


where $w_{t}$ is the real wage and $r_{t+j}$ is the real rate of interest between periods $(t+j)$ and $(t+j+1)$. The first order conditions give an Euler bond equation and a labour supply curve,

$$
\begin{aligned}
c_{t}^{-1}(i) & =\beta\left(1+r_{t}\right) E_{t} c_{t+1}^{-1}(i), \\
\Xi\left(l_{t}(i)\right)^{\kappa} & =c_{t}^{-1}(i) w_{t} .
\end{aligned}
$$

In period $t$ the consumer allocates total consumption $c_{t}(i)$ between (tradable and non tradable) home goods and (imported) foreign goods. The consumption and consumption price indexes are defined according to the CES aggregators,

$$
\begin{aligned}
c_{t}(i) & =\left(\int_{0}^{n_{D, t}} c_{D, t}(\omega, i)^{\frac{\theta-1}{\theta}} d \omega+\int_{0}^{n_{X, t}} c_{X, t}(\omega, i)^{\frac{\theta-1}{\theta}} d \omega+\int_{0}^{n_{X, t}^{*}} c_{M, t}(\omega, i)^{\frac{\theta-1}{\theta}} d \omega\right)^{\frac{\theta}{\theta-1}} \\
P_{c, t} & =\left(\int_{0}^{n_{D, t}} p_{D, t}(\omega)^{1-\theta} d \omega+\int_{0}^{n_{X, t}} p_{X, t}(\omega)^{1-\theta} d \omega+\int_{0}^{n_{X, t}^{*}} p_{M, t}(\omega)^{1-\theta} d \omega\right)^{\frac{1}{1-\theta}}
\end{aligned}
$$

where $\theta$ is the elasticity of substitution across goods; variables $c_{D, t}(\omega, i), c_{X, t}(\omega, i), c_{M, t}(\omega, i)$ represent the individual demand of domestic non traded goods, domestic traded goods and imports; variables $p_{D, t}(\omega), p_{X, t}(\omega), p_{M, t}(\omega)$ are the associated nominal prices. Variables $n_{D, t}$ and $n_{X, t}$ are respectively the number of domestic tradable and non tradable goods, and $n_{X, t}^{*}$ is the number of imported goods. Let $\rho_{j, t}(\omega)=\frac{p_{D, t}(\omega)}{P_{c, t}}$ be the real price of good $\omega$ in the segment $j=\{D, X, M\}$ of the domestic market. We can then write the demand for a representative good as, $c_{j, t}(\omega, i)=\rho_{j, t}(\omega)^{-\theta} c_{t}(i)$.

\subsection{Firms}

The total number of firms operating in each economy is normalized to 1 . Each firm produces a specific good $\omega$. The corresponding production function of the representative firm is, $y_{t}(\omega)=z(\omega) A_{t} \ell_{t}^{d}(\omega)$. Following the literature, firm heterogeneity comes from a specific shock $z(\omega)$ as a deviation from total factor productivity in the economy, $A_{t}$. Firms' productivity $z(\omega)$ is drawn from a Pareto distribution with lower bound $z_{\min }$, and shape parameter $k>(\theta-1)$. $A_{t}$ is homogeneous to all firms and evolves according to: $\log A_{t}=$ $\rho \log A_{t-1}+\xi_{A, t}$, where $\xi_{A, t}$ is a white noise process. Each firm maximizes its profit function,

$$
\pi_{t}(\omega)=\rho_{t}(\omega) y_{t}^{d}(\omega)-\frac{w_{t}}{z(\omega) A_{t}} y_{D, t}^{d}(\omega),
$$

by choosing the optimal selling price according to,

$$
\rho_{t}(\omega)=\frac{\theta}{\theta-1} \frac{w_{t}}{z(\omega) A_{t}}
$$

The level of profit depends on the segment of the goods market on which the firm operates. On the non-traded segment, it faces the demand curve, $y_{t}^{d}(\omega)=\rho_{D, t}^{-\theta}(\omega) c_{t}$, with $c_{t}=\int_{0}^{1} c_{t}(i) d i$, so that the profit function is, $\pi_{D, t}(\omega)=\frac{1}{\theta} \rho_{D, t}^{1-\theta}(\omega) c_{t}$. To become an exporter, the representative firm has to pay an entry cost to get access to the foreign market. That cost of entry is paid in terms of real wage as it is equal to $f_{e} \frac{w_{t}}{A_{t}}$, where $f_{e}$ is a scale parameter. Furthermore, foreign trade is costly as consumers have to pay an iceberg shipping cost $\tau$ to have access to foreign traded goods. Thus, if the representative firm serves the traded segment of 
the goods market, it faces the demand for goods, $y_{t}^{d}(\omega)=\rho_{X, t}^{-\theta}(\omega) c_{t}+\rho_{M, t}^{*-\theta}(\omega) c_{t}^{*}$. The real price of imports is, $\rho_{M, t}^{*}=(1+\tau) q_{t}^{-1} \rho_{X, t}$, where $q_{t}$ is the real exchange rate as the relative price of the foreign consumption price index in terms of the domestic price index. Since the demand addressed to the domestic firm on the traded goods segment is $y_{t}^{d}(\omega)=\rho_{X, t}^{-\theta}(\omega)\left[c_{t}+\right.$ $\left.q_{t}^{\theta}(1+\tau)^{-\theta} c_{t}^{*}\right]$, its profit function writes, $\pi_{X, t}(\omega)=\frac{1}{\theta} \rho_{X, t}^{1-\theta}(\omega)\left[c_{t}+q_{t}^{\theta}(1+\tau)^{-\theta} c_{t}^{*}\right]-f_{e} \frac{w_{t}}{A_{t}}$.

The distribution of firms between the two sectors depends on a cut-off point $z_{X}$. It defines the minimal value of the specific productivity needed to be able to export (ie, to incur the entry cost that must be paid to stay on the traded segment). Domestic firms with $z(\omega)$ lower than $z_{X}$ produce non traded goods, while the others deliver goods in both countries. The cut-off point between the two sectors is determined by the last firm that enters the traded segment. The trigger point is determined by $\pi_{D, t}\left(\omega, z_{X}\right)=\pi_{X, t}\left(\omega, z_{X}\right)$, with $\rho_{D, t}\left(\omega, z_{X}\right)=\rho_{X, t}\left(\omega, z_{X}\right)$. Intuitively, the marginal gain of exporting must compensate for the marginal cost of entering the foreign segment of the goods market. It is defined according to,

$$
z_{X}=\frac{f_{e}}{(\theta-1)}\left(\frac{\theta(1+\tau)}{q_{t}} \frac{w_{t}}{A_{t}}\right)^{\frac{\theta}{\theta-1}} c_{t}^{* 1-\theta} .
$$

In period $t, n_{D, t}$ firms operate in the non traded goods sector while $n_{X, t}$ firms belong to the traded sector. The relative weight of the exporting firms is determined by $n_{X, t}=$ $1-G\left(z_{X}\right)$. Given the Pareto distribution, this leads to $n_{X, t}=z_{\min }^{k} z_{X, t}^{-k}$ and $n_{D, t}=1-z_{\min }^{k} z_{X, t}^{-k}$. The average productivity level of each sector, $\tilde{z}_{D, t}, \tilde{z}_{X, t}$ is then given by $\tilde{z}_{X, t}=\nabla^{\frac{1}{\theta-1}} z_{X, t}$, and $\tilde{z}_{D, t}=\nabla^{\frac{1}{\theta-1}}\left(\frac{z_{\min }-z_{\min }^{k} z_{X, t}^{1-k}}{1-z_{\min }^{k} z_{X, t}^{-k}}\right)$, where $\nabla=\left(\frac{k}{k-(\theta-1)}\right)$. Finally, the average level of activity in each sector is $\tilde{y}_{X, t}=\tilde{\rho}_{X, t}^{-\sigma}\left[c_{t}+q_{t}^{\theta}(1+\tau)^{-\theta} c_{t}^{*}\right]$ and $\tilde{y}_{D, t}=\tilde{\rho}_{D, t}^{-\sigma} c_{t}$, where, $\tilde{\rho}_{X, t}=\frac{\theta}{\theta-1} \frac{w_{t}}{\tilde{z}_{X, t} t_{t}}$, $\tilde{\rho}_{D, t}=\frac{\theta}{\theta-1} \frac{w_{t}}{\tilde{z}_{D, t} A_{t}}$.

\subsection{Aggregation and general equilibrium}

In this fully symmetric case, the aggregate level of output is defined according to,

$$
\begin{aligned}
& y_{t}=\tilde{\rho}_{t} \tilde{y}_{t}=\int_{0}^{1} \rho_{t}(\omega) y_{t}(\omega) d \omega=n_{D, t} \tilde{\rho}_{D, t} \tilde{y}_{D, t}+n_{X, t} \tilde{\rho}_{X, t} \tilde{y}_{X, t}, \\
& y_{t}^{*}=\tilde{\rho}_{t}^{*} \tilde{y}_{t}^{*}=\int_{0}^{1} \rho_{t}^{*}(\omega) y_{t}^{*}(\omega) d \omega=n_{D, t}^{*} \tilde{\rho}_{D, t}^{*} \tilde{y}_{D, t}^{*}+n_{X, t}^{*} \tilde{\rho}_{X, t}^{*} \tilde{y}_{X, t}^{*},
\end{aligned}
$$

and consumption price indexes according to,

$$
\begin{aligned}
& 1=n_{D, t} \tilde{\rho}_{D, t}^{1-\theta}+n_{X, t} \tilde{\rho}_{X, t}^{1-\theta}+n_{x, t}^{*} \tilde{\rho}_{M, t}^{1-\theta}, \\
& 1=n_{D, t}^{*} \tilde{\rho}_{D, t}^{* 1-\theta}+n_{X, t}^{*} \tilde{\rho}_{X, t}^{* 1-\theta}+n_{x, t} \tilde{\rho}_{M, t}^{* 1-\theta} .
\end{aligned}
$$

In this setting, a competitive equilibrium is defined as a sequence of quantities $\left\{Q_{t}\right\}_{t=0}^{\infty}=\left\{c_{t}, c_{t}, y_{t}, y_{t}^{*}, l_{t}, l_{t}^{*}, n_{X, t}, n_{X, t}^{*}, n_{D, t}, n_{D, t}^{*}, \tilde{y}_{X, t}, \tilde{y}_{X, t}^{*}, \tilde{y}_{D, t}, \tilde{y}_{D, t}^{*}\right\}_{t=0}^{\infty}$, and a sequence of real prices $\left\{P_{t}\right\}_{t=0}^{\infty}=\left\{r_{t}, r_{t}^{*}, w_{t}, w_{t}^{*}, \tilde{\rho}_{X, t}, \tilde{\rho}_{X, t}^{*}, \tilde{\rho}_{D, t}, \tilde{\rho}_{D, t}^{*} \cdot q_{t}\right\}_{t=0}^{\infty}$ such that, for any sequence of shocks $\left\{S_{t}\right\}_{t=0}^{\infty}=\left\{A_{t}, A_{t}^{*}\right\}_{t=0}^{\infty}$, the sequence $\left\{Q_{t}\right\}_{t=0}^{\infty}$ meets the first-order conditions for households and firms. It also guarantees labour market clearing $\left(\int_{0}^{1} l_{t}(j) d j=\int_{0}^{1} l_{t}(\omega) d \omega\right.$ and $\left.\int_{0}^{1} l_{t}^{*}(j) d j=\int_{0}^{1} l_{t}^{*}(\omega) d \omega\right)$, goods market equilibrium $\left(\int_{0}^{1} c_{t}(j) d j=\int_{0}^{1} \rho_{t}(\omega) y_{t}(\omega) d \omega\right.$ and $\left.\int_{0}^{1} c_{t}^{*}(j) d j=\int_{0}^{1} \rho_{t}^{*}(\omega) y_{t}^{*}(\omega) d \omega\right)$, and a balanced current account $\left(q_{t} n_{X, t} \tilde{\rho}_{X, t}^{1-\theta} c_{t}^{*}=\right.$ $\left.n_{X, t}^{*} \tilde{\rho}_{X, t}^{* 1-\theta} c_{t}\right)$. 


\subsection{Trade and Business Cycles Synchronization}

We now illustrate how the nature of international trade flows affects the synchronization of activity by analysing the transmission of an asymmetric $1 \%$ increase in domestic productivity. The Impulse Response Functions (IRFs) are computed assigning benchmark values for the parameters of the model. Here $\kappa=5$ is the inverse of the intertemporal elasticity of substitution of labour supply. It lies in the range presented by Canzoneri et al. (2007). The elasticity of substitution in aggregate consumption is equal to $\theta=3.7$ as proposed by Bilbiie et al. (2012). The shape of the Pareto distribution $k$ must exceed $(\theta-1)$ leading us to set $k=3$. The iceberg cost represents $30 \%$ of the value of the traded goods so that $\tau=0.3$. Finally, we assume $\Xi=1, f_{e}=1$, and $\rho=0.9$.

The results of the simulation for this baseline calibration of the model are reported in the figure ?? below. We contrast the IRF of an asymmetric 1\% increase in domestic aggregate productivity in two situations. The plain curves represent the adjustment of the variables when the number of traded varieties evolves. The dotted curves describe the adjustment of the world economy when the number of traded varieties is fixed. As shown in the first graph of figure ??, new trade flows contribute negatively to business cycle synchronization. This increases output dispersion by one half on impact in comparison with the fixed variety version of the model. When trade adjusts at the intensive margin only (dotted lines), a positive productivity shock in the domestic economy increases income and thus aggregate consumption. Following the surge in supply, home goods prices must fall thereby deteriorating the terms of trade by around $0.02 \%$. The surge in aggregate consumption in the domestic economy falls on foreign exports and conversely a part of the additional domestic exports must be bought by foreigners. Thus the relative price of foreign tradables in terms of domestic ones must increase. After an asymmetric productivity shock, the deterioration of the terms of trade implies an international transfer that favors the synchronization of income growth rates.

By contrast, terms of trade movements are severely dampened when trade adjustment operates at both intensive and extensive margins (plain lines in figure ??) as noted by Corsetti et al. (2013). Since the number of firms operating in each sector is endogenous, the supply of foreign exports is now modified. Indeed, the increase in domestic consumption favours the demand for foreign exports. This lowers the cut-off point $z_{X, t}^{*}$ and makes the entry of foreign firms on the tradable segment more profitable. Thus the number of foreign traded goods increases much more than the reduction in individual supply of foreign firms that operate on this market segment. As a consequence, there is a net increase in the supply of foreign goods. On impact, we even notice a small improvement in the terms of trade due to the strong reaction of the foreign supply of tradables. As noted in the graphs, this implies a greater divergence of income growth rates.

Ignoring firm entry, the adjustment of trade between countries relies only on the variations in relative prices. This correction mechanism disappears when trade growth operates at the extensive margin. Thus, endogenous firm entry allows for diverging paths across business cycles. As underlined by the graphs of figure ??, most of the extensive margin of trade comes from the foreign country (around 90\%). Indeed, as the supply of foreign goods increases since it is directly affected by the increase in domestic aggregate consumption. In the meanwhile the increase in the number of traded varieties in the domestic economy is very low (it represents almost $10 \%$ of the increase in the number of foreign traded varieties).

The cut off point in the domestic economy is affected by two opposite effects. On the one hand, productivity gains tie the cut-off point down to stimulate the entry of domestic firms into the export sector. On the other hand, a depressed foreign demand for domestic products 
Fig. 2 IRF to a $1 \%$ domestic productivity shock (plain curves: the number of traded varieties evolves, dotted curves: the number of traded varieties is fixed)
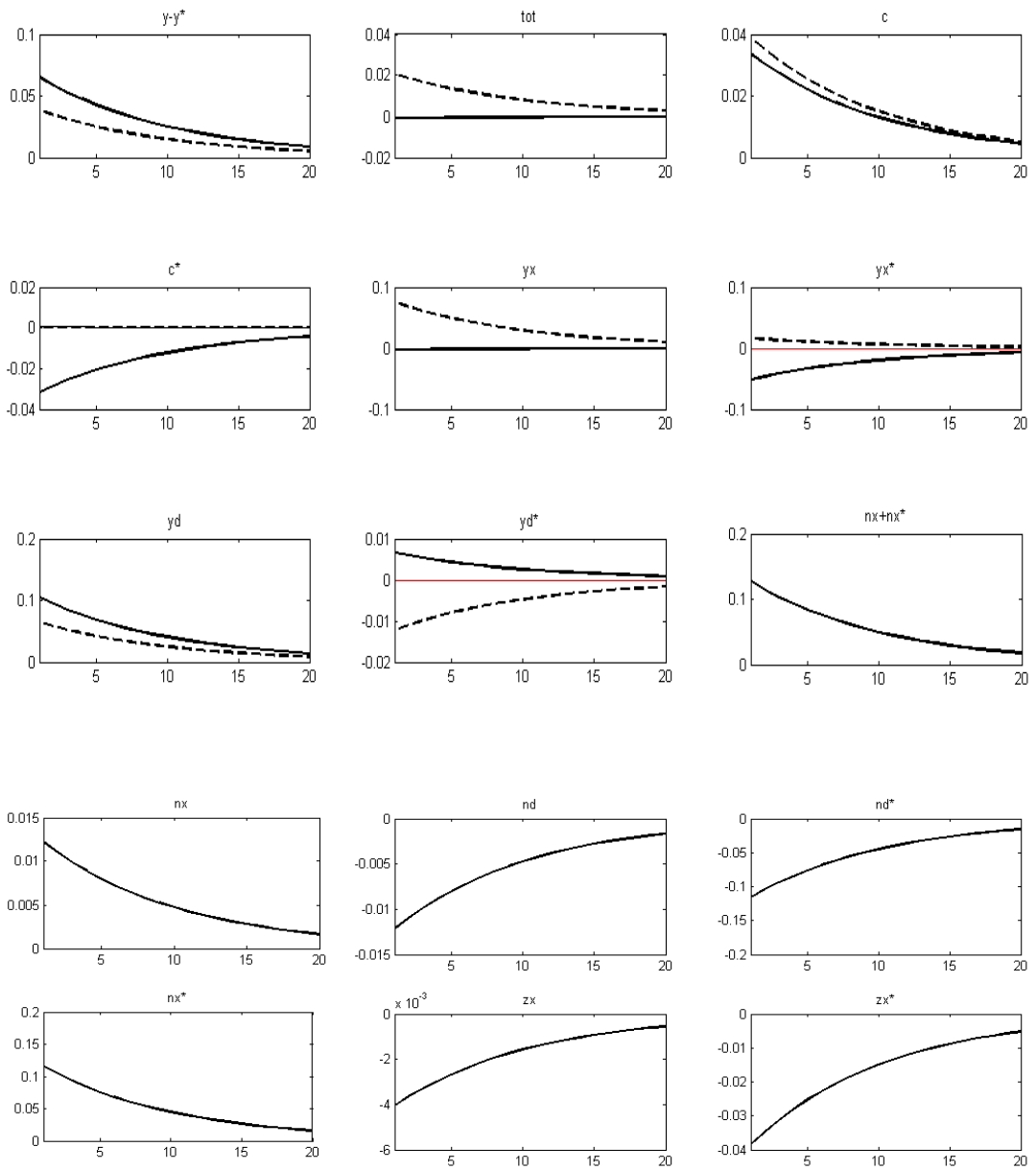

due to the decrease in the foreign aggregate consumption raises the value of the cut off point, which makes firm entry on the traded sector less profitable. Thus, the distribution of firms across sectors remains almost unchanged in the domestic country. Basically, the productivity shock moves the individual supply of domestic non-traded goods upward. Finally, there is a rise in the domestic consumption in terms of both domestic non traded and foreign traded 
goods. New trade flows reduce the need for their relative price to adjust compared with what happens in the baseline case.

In table 3Correlations between NTF and Business Cycle Synchronizationtable.3, we compare the model with a fixed number of Existing Trade Flows only (ETF model) with a model incorporating New Trade Flows (NTF model). We evaluate how results from the benchmark case (first row) vary with deeper good market integration (rows 2 and 3), a reduction in the elasticity of substitution (rows 4 and 5), less firm heterogeneity (rows 6 and 7 ), or more asymmetric productivity shocks (rows 8 and 9).

Table 3 Correlations between NTF and Business Cycle Synchronization

\begin{tabular}{|c|c|c|c|c|c|c|}
\hline \multirow[b]{2}{*}{ Calibration } & \multicolumn{2}{|c|}{ Existing Trade Flows } & \multicolumn{4}{|c|}{ New Trade Flows } \\
\hline & $\sigma_{\left(y-y^{*}\right)}$ & $\sigma_{t o t}$ & $\sigma_{\left(y-y^{*}\right)}$ & $\sigma_{t o t}$ & $\sigma_{\left(n_{X}+n_{X}^{*}\right)}$ & $\rho_{\left(y-y^{*}\right),\left(n_{X}+n_{X}^{*}\right)}$ \\
\hline Benchmark & 2.17 & 1.17 & 3.70 & 0.05 & 6.48 & 0.128 \\
\hline$\tau=0.2$ & 2.17 & 1.17 & 3.67 & 0.03 & 6.56 & 0.127 \\
\hline$\tau=0.1$ & 2.17 & 1.17 & 3.62 & 0.01 & 6.66 & 0.126 \\
\hline$\theta=3.2$ & 2.16 & 1.35 & 2.58 & 0.08 & 6.03 & 0.094 \\
\hline$\theta=2.7$ & 2.14 & 1.58 & 2.12 & 0.01 & 5.15 & 0.085 \\
\hline$k=4$ & 2.17 & 1.17 & 2.99 & 0.25 & 8.19 & 0.095 \\
\hline$k=5$ & 2.17 & 1.17 & 2.72 & 0.31 & 9.71 & 0.082 \\
\hline$\sigma_{A}^{*}=0.6$ & 2.02 & 1.09 & 3.45 & 0.05 & 6.15 & 0.274 \\
\hline$\sigma_{A}^{*}=0.5$ & 1.89 & 1.02 & 3.22 & 0.04 & 5.86 & 0.432 \\
\hline
\end{tabular}

Notes: $\sigma_{x}$ is the standard deviation of $x, \rho_{x, y}$ is the coefficient of correlation between $x$ and $y$.

In the benchmark calibration, the extensive margin of trade weakens the synchronization of business cycles with regards to the ETF model. It also reduces the volatility of the terms of trade. As explained above, the foreign economy reacts by offering more traded varieties following productivity gains by domestic firms. Fluctuations in the terms of trade are thus dampened. The standard deviation of the total number of traded varieties is roughly twice that of business cycle divergence. In this case, the correlation between the degree of business cycle divergence and the increase in the traded varieties is equal to 0.13 . Greater trade integration can come from a reduction in the value of the iceberg shipping cost $\tau$. Firms benefit from a lower value of the cut off points $z_{x}$ and $z_{x}^{*}$, letting the volatility of the ETF model unchanged. By contrast, there is a rising number of traded varieties in the NTF case at the expense of a dampened response of the terms of trade. Cutting transportation costs by half reduces the home bias in consumption which, in turn, promotes business cycle synchronization as $\sigma_{\left(y-y^{*}\right)}$ goes from 3.67 to 3.62 .

A lower elasticity of substitution $(\theta)$ requires a rise in relative prices $\left(\sigma_{t o t}\right)$ in the ETF case whereas the terms of trade play a limited role in the NTF case. In the latter situation, the bulk of adjustment passes through a reduction in the number of traded varieties $\left(\sigma_{\left(n_{X}+n_{X}^{*}\right)}\right)$ that fosters business cycles convergence. However, $\rho_{\left(y-y^{*}\right),\left(n_{X}+n_{X}^{*}\right)}$ is still positive meaning that new trade flows are negatively linked to business cycle synchronization.

Less firms heterogeneity - that is a higher value of the shape parameter $k$ - leads to new trade flows. Productivity gains have a greater impact on the number of traded goods because firms are more concentrated around the cut off points $z_{x}$ and $z_{x}^{*}$. Shocks are more 
symmetric among countries, allowing for more synchronized business cycles. More homogeneous goods lead relative prices to play a greater role in the adjustment process and output to deviate less across countries.

Finally, smaller foreign supply shocks ( $\sigma_{A}^{*}$ goes down) lowers the average volatility of aggregates in the world economy. Instead, it magnifies the correlation between the divergence of business cycles and the number of traded varieties. The reduced synchronization of business cycles comes from new trade flows as countries become more homogeneous.

\section{Econometric Analysis}

We use disaggregated data over the period 1995-2007 for the 11 founding countries ${ }^{3}$ of the EMU to evaluate the empirical relevance of the negative contribution of new trade flows on business cycle synchronization. The aim of our econometric analysis is twofold: first, we evaluate the possibility of either direct and/or indirect impacts of new trade flows on business cycle synchronization and second, we check for the robustness of the existing results, once new trade flows are taken into account. To this end, and consistently with our theoretical setting, we do not consider here the specific consequences of the 2008 financial crisis, an exceptional event by its magnitude.

\subsection{Econometric methodology}

Since the seminal analysis of Frankel and Rose (1998), many refinements have been proposed in the econometric methodology to asses the effect of trade integration on business cycle synchronization. Here we adopt the empirical strategy initially proposed by Imbs (2004) and extended to panel data analysis by Abbott et al. (2008). A panel data model with 3SLS estimators fits well to the question at hand. First, it corrects for the possible endogeneity of trade variables. Second, business cycle correlation may be influenced by unobservable country-pair effects or global factors (Burgert and Dées, 2009). These individual effects may have been important over the period, as these countries have adopted structural reforms to foster nominal convergence before the launching of the euro.

For each country pair $(i, j)$, we estimate the full system,

$$
\begin{aligned}
S Y N_{i j, t} & =\alpha_{0}+\alpha_{1} T R I_{i j, t}+\alpha_{2} N T F_{i j, t}+\alpha_{3} S P E_{i j, t}+\alpha_{4} Z 1_{i j, t}+\alpha_{5} G 1_{i j, t}+\varepsilon_{1 i j, t}, \\
T R I_{i j, t} & =\beta_{0}+\beta_{1} S P E_{i j, t}+\beta_{2} N T F_{i j, t}+\beta_{3} Z 2_{i j, t}+\beta_{4} G 2_{i j, t}+\varepsilon_{2 i j, t}, \\
N T F_{i j, t} & =\phi_{0}+\phi_{1} T R I_{i j, t}+\phi_{2} S P E_{i j, t}+\phi_{3} Z 3_{i j, t}+\phi_{4} G 3_{i j, t}+\varepsilon_{3 i j, t}, \\
S P E_{i j, t} & =\gamma_{0}+\gamma_{1} T R I_{i j, t}+\gamma_{2} N T F_{i j, t}+\gamma_{3} Z 4_{i j, t}+\gamma_{4} G 4_{i j, t}+\varepsilon_{4 i j, t} .
\end{aligned}
$$

Equation (1) describes the determinants of business cycle synchronization between the country pair $i$ and $j$ in year $t\left(S Y N_{i j, t}\right)$. We distinguish the traditional direct effects of trade intensity $\left(T R I_{i j, t}\right)$ and specialization $\left(S P E_{i j, t}\right)$ from the direct effect of new exports $\left(N T F_{i j, t}\right)$. Equation (2) relates trade intensity $\left(T R I_{i j, t}\right)$ to specialization $\left(S P E_{i j, t}\right)$ and new trade flows $\left(N T F_{i j, t}\right)$. Equation (3) is new to the existing literature as it relates new trade flows $\left(N T F_{i j, t}\right)$ to trade intensity $\left(T R I_{i j, t}\right)$ and specialization $\left(S P E_{i j, t}\right)$. Equation (4) explains specialization $\left(S P E_{i j, t}\right)$ by trade intensity $\left(T R I_{i j, t}\right)$ and new trade flows $\left(N T F_{i j, t}\right)$.

\footnotetext{
3 Austria, Belgium-Luxemburg, Finland, France, Germany, Ireland, Italy, Netherlands, Portugal, Spain.
} 
Turning now to the variables, we define New Trade Flows between countries $i$ and $j$ in period $t\left(N T F_{i j, t}\right)$ as the ratio between the value of new export flows ${ }^{4}$ from country $i$ to country $j$ in period $t\left(X_{i j, t}^{n}=\sum_{k} X_{i j, k, t}^{n}\right.$ where $k$ is the variety index) and the value of total exports from country $i$ to country $j$ in period $t\left(X_{i j, t}\right)$, ie, NTF $F_{i j, t}=\frac{\sum_{k} X_{i j, k, t}^{n}}{X_{i j, t}}$. This definition has two advantages compared to the sole number of new traded goods: first it takes into account the heterogeneity of new flows in terms of selling prices; second it provides a definition of new trade flows that can be measured on the same metric as trade intensity. To measure business cycle synchronization we follow Inklaar et al. (2008), and compute the Fisher transform of correlation between countries $i$ and $j$ in period $t$ defined as $S Y N_{i j, t}=$ $\frac{1}{2} \ln \left(\frac{1+C_{i j, t}}{1-C_{i j, t}}\right)$. Here $C_{i j, t}$ is the pairwise correlation coefficient for countries $(i, j)$ in period $t$ using GDP data from the OECD database ${ }^{5}$. Trade intensity is the ratio of the sum of total exports from country $i$ to country $j\left(X_{i j, t}\right)$ and imports of country $i$ from country $j\left(M_{i j, t}\right)$ over country $i \operatorname{GDP}\left(Y_{i, t}\right)$, ie $T R I_{i j, t}=\frac{X_{i j, t}+M_{i j, t}}{Y_{i, t}}$. Following Imbs (2004) and Inklaar et al. (2008), specialization is defined as the absolute difference of the GDP share of an industry in two countries, ie Specia $i j, t=\sum_{s}\left|V_{i s}-V_{j s}\right|$. The corresponding data on 27 sectors of goods and services come from the OECD database.

The sets $Z 1_{i j, t}, Z 2_{i j, t}, Z 3_{i j, t}$ and $Z 4_{i j, t}$ control for financial integration, similarity of economic policies and the volatility of real exchange rates. We account for the similarity of macroeconomic policies in two ways. We compute yearly averages of the standard deviation of monthly real interest rate differentials $\left(I F I 1_{i j, t}\right)$ using nominal interest rates and consumer price indices. Monetary conditions are captured through three-month interest rates. We use the OECD data.

We consider the absolute difference between the net foreign assets $\left(N F A_{i j, t}\right)$ of a countrypair as a proxy of bilateral capital restrictions $\left(I F I 2_{i j, t}\right)$ following Imbs (2004) and Inklaar et al. (2008). The NFA annual data series come from the updated database of Lane and MilesiFeretti (2007). We use absolute differences between the GDP ratios of the cumulated current accounts for each country-pair. We account for financial linkages between country pairs as suggested by Otto et al. (2001). Real equity returns are computed on the basis of monthly nominal stock market indices and consumer price indices $\left(I F I 3_{i j, t}\right)$. We use the Harmonized Consumer Price Index as deflator. Data come from the OECD.

Following Darvas et al. (2005), the adjusted government primary balance (in percent of GDP) measures fiscal policy divergence $\left(F I S_{i j, t}\right)$. The logarithm of the standard deviation of the difference of real bilateral exchange rates $\left(R E R_{i j, t}\right)$ are taken from the Pacific Retrieval Interface of the British Columbia University.

The sets $G 1_{i j, t}, G 2_{i j, t}, G 3_{i j, t}$ and $G 4_{i j, t}$ combine gravity variables. As stressed by Clark and van Wincoop (2001), output correlations among countries (or regions) can also be influenced by distance factors. Dummy variables from the CEPII bilateral distance database are used to control for contiguity $\left(C O N_{i j}\right)$ and for a common language $\left(L A N_{i j}\right)$. Economic distance between pairs of countries $\left(D I S_{i j, t}\right)$ is proxied by the log of the distance (in kilometers) between their capital cities. Finally, we also control for the effect of size on trade by an additional variable based on per capita output in the two economies $\left(S I Z_{i j}\right)$.

\footnotetext{
4 Exports are new if their value are positive at the period $t$ and null a the period $t-1$.

5 A detailed description of the variables, data and sources is presented in appendix.
} 
3.2 Simultaneous-equations estimates

We report results from a 3SLS panel estimation of equations (1)-(4) using the Random Effect (RE) estimator ${ }^{6}$. The left-hand side of table 4Determinants of synchronization: 3SLS-RE panel results over 1995-2007table.4 reports results from a benchmark model ignoring new trade flows.

We find a robust and positive influence (0.206) of trade intensity on business cycle comovements as previously obtained by Imbs (2004), Baxter and Kouparitsas (2005), Inklaar et al. (2008) and Abbott et al. (2008). Specialization has a negative impact on synchronization (-1.020). This supports previous empirical findings such as Imbs (2004) and KalemliOzcan et al. (2009). Conversely, higher trade intensity decreases the specialization of the trading partners (-0.143). According to the Ricardian approach, specialization increases bilateral trade (0.674). However bilateral trade intensity is primarily influenced by gravity factors: the more distant two euro members are, the less they trade with each other, a common language tends to boost bilateral trade significantly but there is no significant country size effect.

Finally, specialization increases when two countries share a common border. Having the same language has no significant effect on production structures.

The right hand-side of table 4Determinants of synchronization: 3SLS-RE panel results over 1995-2007table.4 takes into account new trade flows as a specific component of trade integration in Europe. Adding this new variable to the system reduces the impact of trade intensity on business cycle synchronization by more than 40 percent (from 0.206 to 0.111 ). In the same way, the effect of specialization on business cycle synchronization is also reduced by $40 \%$ (from -1.020 to -0.537 ). Given table 4Determinants of synchronization: 3SLS-RE panel results over 1995-2007table.4, the negative contribution of new trade flows on business cycle comovements is significant at $1 \%(-0.042)$. Accounting for new trade flows in the 3SLS-RE panel estimation we find that specialization is now positively affected by trade intensity. This result is in line with Krugman's view about the possible negative consequences of trade integration. International trade can be viewed as a source of heterogeneity within a currency union. In contrast the impact of specialization on trade intensity remains unchanged. New trade flows have no significant direct impact on trade intensity while trade intensity reduces new trade flows. This feature can be explained as follows: when trade intensity is high, this reduces the possibility of creating new bilateral trade relations.

The mixed effect of trade integration on business cycle co-movements has been already noticed in the literature. As concerns the New EU Member States, Babetski (2005) finds a positive relationship between the correlation of aggregate demand shocks (with either Germany or the European Union) and trade intensity. By contrast, shocks to the supply side become less synchronized when intra-industry trade expands.

New trade flows also tend to increase the specialization of countries. This can occur if new traded flows concern an existing traded sector in which the country is already specialized. Finally specialization has a positive effect on trade intensity, as less diversified countries tend to have a higher bilateral trade. It also promotes new traded flows since, once a country becomes more specialized, it can export more new varieties. As a final remark, the roles played by financial integration and policy coordination are more cumbersome. As described by the negative influence of the FIS variable in table 4Determinants of synchronization: 3SLS-RE panel results over 1995-2007table.4, business cycles tend to be less synchronized in case of diverging fiscal paths between Member States. Accordingly, activity

\footnotetext{
6 The Hausmann test shows that a random effect representation outperforms the fixed effect alternative.
} 
Table 4 Determinants of synchronization: 3SLS-RE panel results over 1995-2007.

\begin{tabular}{|c|c|c|c|c|c|c|c|}
\hline & \multicolumn{3}{|c|}{ Benchmark Model } & \multicolumn{4}{|c|}{ Model with New Trade Flows } \\
\hline & SYN & TRI & SPE & SYN & TRI & NTF & SPE \\
\hline \multirow[t]{2}{*}{ TRI } & 0.206 & & -0.143 & 0.111 & & -9.978 & -0.538 \\
\hline & $(6.25)^{* * *}$ & & $(2.26)^{* *}$ & $(2.65)^{* * *}$ & & $(2.08)^{* *}$ & $(2.66)^{* * *}$ \\
\hline \multirow[t]{2}{*}{ NTF } & & & & -0.042 & 0.027 & & 0.162 \\
\hline & & & & $(3.97)^{* * *}$ & $(0.53)$ & & $(5.57)^{* * *}$ \\
\hline \multirow[t]{2}{*}{ SPE } & -1.020 & 0.674 & & -0.537 & 0.727 & 14.446 & \\
\hline & $(5.36)^{* * *}$ & $(2.38)^{* *}$ & & $(2.48)^{* *}$ & $(2.42)^{* *}$ & $(3.80)^{* * *}$ & \\
\hline \multirow[t]{2}{*}{ FISC } & -0.007 & & & -0.004 & & & \\
\hline & $(1.86)^{*}$ & & & $(1.08)$ & & & \\
\hline \multirow[t]{2}{*}{ IFI1 } & 0.011 & & & 0.015 & & & \\
\hline & $(3.33)^{* * *}$ & & & $(4.01)^{* * *}$ & & & \\
\hline \multirow[t]{2}{*}{ IFI2 } & 0.077 & & & 0.072 & & & \\
\hline & $(5.85)^{* * *}$ & & & $(5.30)^{* * *}$ & & & \\
\hline \multirow[t]{2}{*}{ RER } & -0.012 & 0.014 & & -0.011 & 0.014 & 0.182 & \\
\hline & $(5.17)^{* * *}$ & $(5.81)^{* * *}$ & & $(4.74)^{* * * *}$ & $(4.34)^{* * *}$ & $(2.58)^{* * *}$ & \\
\hline \multirow[t]{2}{*}{ SIZ } & & 0.137 & 0.177 & & 0.117 & -2.661 & 0.486 \\
\hline & & $(2.18)^{* *}$ & $(7.15)^{* * *}$ & & $(1.43)$ & $(3.50)^{* * *}$ & $(6.63)^{* * *}$ \\
\hline \multirow[t]{2}{*}{ DIS } & & $-1.0 \times 10^{-4}$ & $6.9 \times 10^{-6}$ & & $-1.3 \times 10^{-4}$ & $5.8 \times 10^{-4}$ & $-2.8 \times 10^{-4}$ \\
\hline & & $(7.09) * * *$ & $(0.80)$ & & (1.40) & (1.31) & $(4.56)^{* * *}$ \\
\hline \multirow[t]{2}{*}{ LAN } & & 0.162 & -0.021 & & 0.175 & 2.642 & -0.044 \\
\hline & & $(6.43)^{* * * *}$ & $(1.90)^{*}$ & & $(4.34)^{* * *}$ & $(2.91)^{* * *}$ & (1.37) \\
\hline \multirow[t]{2}{*}{$\mathrm{CON}$} & & 0.458 & 0.176 & & 0.458 & 4.000 & -0.383 \\
\hline & & $(11.37)^{* * *}$ & $(4.56)^{* * * *}$ & & $(10.63)^{* * *}$ & $(1.71)^{*}$ & $(3.19)^{* * *}$ \\
\hline \multirow[t]{2}{*}{ IFI3 } & & & 0.063 & & & & 0.069 \\
\hline & & & $(7.73)^{* * *}$ & & & & $(3.48)^{* * *}$ \\
\hline \multirow[t]{2}{*}{ Const. } & 0.105 & -0.119 & -0.143 & 0.096 & -0.104 & 2.681 & -0.445 \\
\hline & $(9.08)^{* * *}$ & $(1.79)^{*}$ & $(5.48)^{* * * *}$ & $(8.17)^{* * * *}$ & $(1.20)$ & $(3.36)^{* * *}$ & $(5.89)^{* * *}$ \\
\hline
\end{tabular}

Sample size is 1080. Absolute value of $z$ statistics in parentheses.

$*, * *, * * *$ significant results at $10 \%, 5 \%$ and $1 \%$ respectively.

comovements are reduced as domestic and foreign monetary policies become more similar: the lower volatility of the short-term interest rate differential (IFI1) is, the higher the correlation is between business cycles. These findings constrast with the absence of a policy coordination effect on the comovements in the European cycles as documented in Clark and van Wincoop (2001). As argued by the former authors, this lack of evidence may come from the ambiguous role of national policies that can either boost or dampen cyclical fluctuations in output. Financial integration has a significantly positive influence on the coupling of business cycles in the euro area. Smaller deviations in net foreign assets relative to GDP (IFI2) or less volatile real bilateral exchange rates $(R E R)$ strengthen the comovements of national GDPs. This channel has been neglected by Rose (1998) and Kose et al. (2003). For Dées and Zorell (2012), it is difficult to isolate the role of bilateral capital flows on business cycles correlation. In contrast with these authors, we rely on and Milesi-Ferretti's computations of net foreign assets and make no distinction between equities, foreign direct investment, and bonds. This feature may explain the departure of our results from these previous findings. 
As reported in table 4Determinants of synchronization: 3SLS-RE panel results over 1995-2007table.4, the impact of new trade flows on business cycle synchronization is significant but weak with regard to trade intensity and specialization. However this direct effect offers only a partial view of the impact of new trade flows on business cycle comovements, given the interplay of trade variables. Following Imbs (2004) and Dées and Zorell (2012), we compute the overall effect of trade intensity, new trade flows and specialization on business cycle synchronization.

\subsection{Direct and indirect effects of new trade flows}

Table 5Decomposition of the effects on business cycles comovementstable.5 decomposes the overall effect of each of these variables. Disentangling the nature of the indirect effects, one shall note that new trade flows act mainly as a propagation mechanism whereas it plays a minor role as an impulse variable. As an amplifying factor it works through both trade intensity and specialization. Remarkably, the overall effect of new trade flows depends on the indirect impact through the specialization channel $\left(\alpha_{3} \gamma_{2}=-0.087\right)$ that is twice the value of its direct effect on business cycle synchronization $\left(\alpha_{2}=-0.042\right)$.

Table 5 Decomposition of the effects on business cycles comovements.

\begin{tabular}{|c|c|c|c|c|c|c|}
\hline & \multirow{2}{*}{ Overall } & \multirow{2}{*}{ Direct } & \multirow{2}{*}{ Indirect } & \multicolumn{3}{|c|}{ Propagation through } \\
\hline & & & & TRI & SPE & NTF \\
\hline & \multicolumn{6}{|c|}{ Benchmark system } \\
\hline \multirow[t]{2}{*}{ TRI } & & $\alpha_{1}$ & & & $\alpha_{3} \gamma_{1}$ & \\
\hline & $0.352^{* * *}$ & $0.206^{* * *}$ & $0.146^{* *}$ & & $0.146^{* *}$ & \\
\hline \multirow[t]{3}{*}{ SPE } & & $\alpha_{3}$ & & $\alpha_{1} \beta_{1}$ & & \\
\hline & $-0.881^{* * *}$ & $-1.020^{* * *}$ & $0.139^{* *}$ & $0.139^{* *}$ & & \\
\hline & \multicolumn{6}{|c|}{ System with new trade flows } \\
\hline \multirow[t]{2}{*}{ TRI } & & $\alpha_{1}$ & & & $\alpha_{3} \gamma_{1}$ & $\alpha_{2} \phi_{1}$ \\
\hline & $0.821^{* * *}$ & $0.111^{* * *}$ & $0.710^{* * *}$ & & $0.289^{*}$ & $0.421^{*}$ \\
\hline \multirow[t]{3}{*}{ SPE } & & $\alpha_{3}$ & & $\alpha_{1} \beta_{1}$ & & $\alpha_{2} \phi_{2}$ \\
\hline & $-1.067^{* * *}$ & $-0.537^{* * *}$ & $-0.529^{* * *}$ & $0.080^{*}$ & & $-0.610^{* * *}$ \\
\hline & & $\alpha_{2}$ & & $\alpha_{1} \beta_{2}$ & $\alpha_{3} \gamma_{2}$ & \\
\hline NTF & $-0.126^{* * *}$ & $-0.042^{* * *}$ & $-0.084^{* *}$ & 0.003 & $-0.087^{* *}$ & \\
\hline
\end{tabular}

$*, * *, * * *$ significant results at $10 \%, 5 \%$ and $1 \%$ respectively.

The key role of new trade flows as an amplifying channel can easily be observed by contrasting the two estimated models. First, ignoring new trade flows as in the benchmark case, the overall effect of trade intensity $(0.352)$ is mainly explained by the direct impact $\left(\alpha_{1}=0.206\right)$ already noted in table 4Determinants of synchronization: 3SLS-RE panel results over 1995-2007table.4. The indirect effect $\left(\alpha_{3} \gamma_{1}=0.146\right)$ is positive as trade intensity reduces specialization that itself affects negatively business cycle synchronization.

The model that takes into account new trade flows gives a new picture for the relative strength of direct and indirect channels. The net increase in the overall effect is now explained by the indirect channels. The direct impact of trade intensity now represents $20 \%$ of the total effect $\left(\alpha_{1}=0.111\right)$ while its indirect impact is more than six times higher (that 
is $40 \%$ through specialization and $60 \%$ through new trade flows). This feature also characterises the impact of specialization on business cycle synchronization. In the benchmark model, the negative effect of specialization on business cycle comovements $\left(\alpha_{3}=-1.020\right)$ is partially dampened by the indirect positive effect of specialization on trade intensity $\left(\alpha_{1} \beta_{1}=0.139\right)$. In the competing model, the overall negative effect of specialization on business cycle synchronization is strengthened through the indirect channel of new trade flows. As noted previously for trade intensity, the direct effect is divided by two $\left(\alpha_{3}=-0.537\right)$ to equate the size of the indirect effect, which is mostly explained by the new trade flows channel $\left(\alpha_{2} \phi_{2}=-0.610\right)$.

\section{Conclusion}

This paper has investigated the impact of trade integration on business cycle synchronization for the founding countries of the EMU. We have first built an illustrative DSGE model highlighting the role of the terms of trade in the coupling of business cycles across countries. Synchronization is weakened when new firms export as a response to productivity gains. Then, we have extended the standard approaches promoted by Imbs (2004), Inklaar et al. (2008) and Abbott et al. (2008) to take into account the trade effect of the euro on the extensive margin of international trade. Using a panel data approach and tackling the endogeneity issue we have found that trade intensity has still a direct positive effect. This contrasts with the negative impact of new trade flows and specialization on business cycle comovements. However the direct effect of new trade flows is quite weak. Furthermore, we have decomposed the overall impact of each trade variable on business cycle synchronization. This delivers a new picture of the role of new trade flows on business cycle comovements as this variable acts mainly as a propagation mechanism. This indirect channel represents at least as much as the respective direct impact of trade intensity and specialization on business cycle synchronization.

Two main implications should be drawn from this paper. First, it underlines the role of indirect channels to assess the overall impact of trade intensity and specialization on business cycle synchronization. This pattern, already noted by Imbs (2004) and Dées and Zorell (2012) for financial factors, also operates through the increase in the number of traded varieties. Second, despite greater synchronization within EMU (Ferreira-Lopes and Pina, 2011), our results show that the composition of trade between the intensive and extensive margins (here measured by new trade flows) also matters for the cohesion of business cycles within a currency area. From this perspective, new trade flows have a similar impact as specialization in that it dampens output comovements. By so a key component of the trade effect of the euro has clearly played against the synchronization of the European business cycles.

Whether greater business cycle synchronization is a positive or a negative consequence of deeper integration among the European economies remains an open issue. Firstly, Fidrmuc and Korhonen (2003) argue that a high degree of synchronization may result from strong asymmetries on both shocks and output responses to these disturbances. Moreover, countries belonging to the same currency area but following divergent paths may benefit from the risk diversification in international asset portfolios, in other words risk sharing. Such gains are found much higher in the new than in the old members of the euro (Demyanyk and Volosovych, 2008). It is also doubtful that the monetary union would benefit from additional entries as shown by Imbs and Mauro (2007). 
Secondly, and perhaps more importantly, De Haan et al. (2008) further suggest that closer output comovements may raise the concern for crisis contagion. As regards the current debate about the 2008 financial crash, a great collapse occurred in trade flows. In the French case, Bricongne et al. (2012) observe that the extensive margin of trade has only slightly contributed to the drop in French exports. As a rejoinder, Behrens et al. (2013) conclude that the fall in exports that followed the 2008 financial crisis was mainly driven by a cut in the intensive margin as opposed to the extensive margin that was almost unaffected. Regarding the impact on business cycle synchronization, trade has played almost no role since 2008 according to Imbs (2010). Rather, as he suggests, the credit channel may have reached a critical level beyond which domestic activity was no more resilient to an adverse financial shock. This is a distinctive feature that differentiates the advanced countries from the emerging world. In the latter group, trade linkages still played a major role given lessdeveloped financial systems.

Thus our study should be considered as a first step for a better understanding of the role played by trade margins on business cycle synchronization.

Acknowledgements We would like to thank Nathalie Colombier for helpful assistance. We are also grateful to Angela Cheptea, Valérie Mignon, and Daniel Mirza.

\section{References}

1. Abbott A, Easaw J , Xing T (2008)Trade Integration and Business Cycle Convergence: Is the Relation robust across Time and Space?, Scandinavian Journal of Economics 110(2):403-417

2. Babetskii, I. (2005) Trade Integration and Synchronization of Shocks, Economics of Transition, 13(1), 105-138.

3. Baxter, M., and M. A. Kouparitsas (2003) Trade Structure, Industrial Structure, and International Business Cycles, American Economic Review, 93(2), 51-56.

4. Baxter, M., and M. A. Kouparitsas (2005) Determinants of Business Cycle Comovement: a Robust Analysis, Journal of Monetary Economics, 52(1), 113-157.

5. Behrens K., G. Corcos and G. Mion (2013) Trade Crisis? What Trade Crisis?, The Review of Economics and Statistics, 95(2), 702-709.

6. Berger, H., and V. Nitsch (2008) Zooming out: The Trade Effect of the Euro in Historical Perspective, Journal of International Money and Finance, 27(8), 1244-1260.

7. Bergin, P. R., and C.-Y. Lin (2009) Exchange Rate Regimes and the Extensive Margin of Trade, in NBER International Seminar on Macroeconomics 2008, NBER Chapters, pp. 201-227. National Bureau of Economic Research, Inc.

8. Bergin, P. R., and C.-Y. Lin (2012) The Dynamic Effects of a Currency Union on Trade, Journal of International Economics, 87(2), 191-204.

9. Bilbiie, F. O., F. Ghironi, and M. J. Melitz (2012) Endogenous Entry, Product Variety, and Business Cycles, Journal of Political Economy, 120(2), 304-345.

10. Bricongne, J.-C., L. Fontagné, G. Gaulier, D. Taglioni, and V. Vicard (2012) Firms and the global crisis: French exports in the turmoil, Journal of International Economics, 87(1), 134-146.

11. Burgert M., and S. Dées (2009), Forecasting Wolrd Trade: Direct Versus "Bottom-Up" Approaches, Open Economies Review, 20(3), 385-402.

12. Canzoneri, M. B., R. E. Cumby, and B. T. Diba (2007) Euler Equations and Money Mar- ket Interest Rates: A Challenge for Monetary Policy Models, Journal of Monetary Economics, 54(7), 1863-1881.

13. Clark, T. E., and E. van Wincoop (2001) Borders and Business Cycles, Journal of International Economics, 55(1), 59-85. 
14. Corsetti, G., P. Martin, and P. Pesenti (2013) Varieties and the Transfer Problem, Journal of International Economics, 89(1), 1-12.

15. Darvas, Z., A. K. Rose, and G. Szapary (2005) Fiscal Divergence and Business Cycle Synchronization: Irresponsibility is Idiosyncratic, in NBER International Seminar on Macroeconomics 2005, NBER Chapters, pp. 261-298. National Bureau of Economic Research, Inc.

16. Dées, S., and N. Zorell (2012) Business Cycle Synchronisation: Disentangling Trade and Financial Linkages, Open Economies Review, vol. 23(4), 623-643.

17. De Haan, J., R. Inklaar and R. Jong-A-Pin, (2008) Will Business Cycles In The Euro Area Converge? A Critical Survey Of Empirical Research, Journal of Economic Surveys, 22(2), 234-273.

18. Demyanyk, Y. and V. Volosovych, (2008), Gains from Financial Integration in the European Union: Evidence for New and Old Members, Journal of International Money and Finance, vol. 27(2), 277-294.

19. Ferreira-Lopes A., and A. Pina, (2011) Business Cycles, Core, and Periphery in Monetary Unions: Comparing Europe and North America, Open Economies Review, 22(4), 565-592.

20. Fidrmuc, J. and I. Korhonen, (2003) Similarity of Supply and Demand Shocks between the Euro Area and the CEECs, Economic Systems, Elsevier, 27(3), 313-334.

21. Flam, H., and H. Nordström (2006) Euro Effects on the Intensive and Extensive Margins of Trade, CESifo Working Paper Series 1881, CESifo Group Munich.

22. Fonseca, R., L. Patureau, and T. Sopraseuth (2010) Business Cycle Comovement and Labor Market Institutions: An Empirical Investigation, Review of International Economics, 18(5), 865-881.

23. Frankel, J. A., and A. K. Rose (1998) The Endogeneity of the Optimum Currency Area Criteria, Economic Journal, 108(449), 1009-25.

24. Gaulier, G., and S. Zignago (2009) BACI: International Trade Database at the Product- level: The 19942007 Version, Working Paper 2009-05, CEPII Research Center.

25. Harris, M. N., L. Kónya, and L. Mátyás (2012) Some Stylized Facts about International Trade Flows, Review of International Economics, 20(4), 781-792.

26. Havránek, T. (2010) Rose Effect and the Euro: is the Magic Gone?, Review of World Economics, 146(2), 241-261.

27. Imbs, J. (2004) Trade, Finance, Specialization, and Synchronization, The Review of Economics and Statistics, 86(3), 723-734.

28. Imbs, J. (2010) The First Global Recession in Decades, IMF Economic Review, 58(2), 327-354.

29. Imbs, J. and P. Mauro, (2007), Pooling Risk Among Countries, IMF Working Papers, 07/132.

30. Inklaar, R., R. Jong-A-Pin, and J. de Haan (2008) Trade and Business Cycle Synchronization in OECD Countries-A re-examination, European Economic Review, 52(4), 646-666.

31. Kalemli-Ozcan, S., E. Papaioannou, and J. L. Peydro-Alcalde (2009) Financial Integration and Business Cycle Synchronization, Discussion Paper 7292, C.E.P.R. Discussion Papers.

32. Kalemli-Ozcan, S., B. E. Sørensen, and O. Yosha (2003) Risk Sharing and Industrial Specialization: Regional and International Evidence, American Economic Review, 93(3), 903-918.

33. Kalemli-Ozcan, S., B. E. Sørensen, and O. Yosha (2005) Who will Own Europe? The Internationalization of Asset Ownership in the EU Today and in the Future, chap. Asymmetric Shocks and Risk Sharing in a Monetary Union: Updated Evidence and Policy Implications for Europe, pp. 173-206. Cambridge University Press.

34. Kose, M. A., E. S. Prasad, and M. E. Terrones (2003): How Does Globalization Affect the Synchronization of Business Cycles?, American Economic Review, 93(2), 57-62.

35. Lane, P. R., and G. M. Milesi-Ferretti (2007) The External Wealth of Nations Mark II: Revised and Extended Estimates of Foreign Assets and Liabilities, 1970-2004, Journal of International Economics, 73(2), 223-250.

36. Lee, J., and W. Rhee (2013) Financial Factors in the Business Cycle of a Small Open Economy: the Case of Korea, Open Economies Review, 24(5), 881-900.

37. Otto, G., G. Voss, and L. Willard (2001) Understanding OECD Output Correlations,? RBA Research Discussion Papers rdp2001-05, Reserve Bank of Australia.

38. Rose, A. K., and T. D. Stanley (2005) A Meta-Analysis of the Effect of Common Currencies on International Trade, Journal of Economic Surveys, 19(3), 347-365. 


\section{Appendix}

\begin{tabular}{|c|c|c|c|}
\hline Variables & Description & Measure & Data Source \\
\hline SYN & $\begin{array}{l}\text { Business cycle } \\
\text { synchronization index }\end{array}$ & $\begin{array}{l}S Y N_{i j, t}=\frac{1}{2} \ln \left(\frac{\left(1+C_{i j, t}\right)}{\left(1-C_{i j, t}\right)}\right) \\
C_{i j, t} \text { is the pairwise correlation coefficient } \\
\text { between growth rate of HP-filtered GDP series }\end{array}$ & OECD \\
\hline TRI & Bilateral Trade Intensity & $\begin{array}{l}T R I_{i j, t}=\frac{X_{i j, t}+M_{i j, t}}{Y_{i, t}} \text { with } X, M \text { exports } \\
\text { and imports and } Y \text { the GDP. }\end{array}$ & OECD \\
\hline NTF & $\begin{array}{l}\text { Bilateral share of New } \\
\text { Trade Flows }\end{array}$ & $\begin{array}{l}N T F_{i j, t}=\frac{\sum_{k} X_{i j, k, t}^{n}}{\sum_{k} X_{i j, k, t}} \text { with } X_{i j, t}^{n} \\
\text { value of new exports at the period } t\end{array}$ & CEPII, BACI \\
\hline SPE & Sectoral specialization & $\begin{array}{l}S P E=\sum_{s}\left|V_{i s}-V_{j s}\right| \\
V_{i s} \text { as the GDP share of industry } s \\
\text { in country } i \text {. }\end{array}$ & OECD \\
\hline FIS & $\begin{array}{l}\text { Divergence of cyclically } \\
\text { adjusted fiscal positions }\end{array}$ & $\begin{array}{l}F I S=\left|B u d g_{i t}-B u d g_{j t}\right| \\
\text { Budg: net fiscal lend/borrowing } \\
\text { as \% of potential GDP. }\end{array}$ & OECD \\
\hline IFI1 & $\begin{array}{l}\text { Volatility of the spread } \\
\text { of 3-month interest rates }\end{array}$ & $I F I 1_{i j, t}=\ln \left(\sigma\left(r_{i, t}-r_{j, t}\right)\right)$ & OECD \\
\hline IFI2 & $\begin{array}{l}\text { Divergence between } \\
\text { net foreign assets }\end{array}$ & $I F I 2_{i j, t}=\left|\frac{N F A_{i, t}}{G D P_{i, t}}-\frac{N F A_{j, t}}{G D P_{j, t}}\right|$ & $\begin{array}{l}\text { Lane \& Milesi-Feretti's } \\
\text { (2007) database }\end{array}$ \\
\hline IFI3 & $\begin{array}{l}\text { Volatility of real } \\
\text { equity returns }\end{array}$ & $\begin{array}{l}I F I 3_{i j, t}=\ln \left(\sigma\left(R_{i, t}-R_{j, t}\right)\right) \\
\text { with } R \text { the real rate of return } \\
\text { the stock market index. }\end{array}$ & OECD \\
\hline RER & $\begin{array}{l}\text { Volatility of the real } \\
\text { bilateral exchange rate }\end{array}$ & $\begin{array}{l}R E R_{i j, t}=\ln \left(\sigma\left(e_{i j, t}\right)\right) \\
\text { with } e_{i, t} \text { the US dollar rate for the } \\
\text { domestic currency. }\end{array}$ & $\begin{array}{l}\text { British Columbia } \\
\text { University }\end{array}$ \\
\hline SIZ & $\begin{array}{l}\text { Product of GDPs } \\
\text { (in logs) }\end{array}$ & $S I Z=\ln \left(Y_{i, t} \times Y_{j, t}\right)$ & CEPII \\
\hline DIS & $\begin{array}{l}\text { Log of distance (in } \mathrm{Km} \text { ) } \\
\text { between capital cities }\end{array}$ & & CEPII \\
\hline LAN & Dummy for common language & & CEPII \\
\hline $\mathrm{CON}$ & Dummy for common border & & CEPII \\
\hline
\end{tabular}

